The Catholic University of America, Columbus School of Law

CUA Law Scholarship Repository

1971

\title{
Lawyers and Public Criticism: Challenge and Response in Nineteenth-Century America
}

Maxwell Bloomfield

The Catholic University of America, Columbus School of Law

Follow this and additional works at: https://scholarship.law.edu/scholar

Part of the Legal History Commons

\section{Recommended Citation}

Maxwell Bloomfield, Lawyers and Public Criticism: Challenge and Response in Nineteenth-Century America, 15 AM. J. LEGAL HIST. 269 (1971).

This Article is brought to you for free and open access by the Faculty Scholarship at CUA Law Scholarship Repository. It has been accepted for inclusion in Scholarly Articles and Other Contributions by an authorized administrator of CUA Law Scholarship Repository. For more information, please contact edinger@law.edu. 


\title{
Lawyers and Public Criticism: Challenge and Response in Nineteenth-Century America
}

\author{
by MAXWELL BLOOMFIELD*
}

In the folklore of American legal history the middle decades of the nineteenth century mark the nadir of professionalism in national life. While acknowledging the brilliant achievements of individual practitioners and judges during the years from 1830 to 1870, commentators from Charles Warren and Roscoe Pound to W. Raymond Blackard and Anton-Hermann Chroust have insisted upon the overall deterioration of the bar under the assaults of a militant democracy. The standard picture of professional development in the United States begins with a Golden Age of jurisprudence in the early Republic, fostered by a self-regulating fraternity of educated judges and lawyers. Then come the Barbarian Invasions, as the semi-literate masses force their way into legal practice, aided by sympathetic state legislatures. Finally, after several decades of disorder and demoralization, an elite leadership arises to purge the profession of its populist standards of recruitment and achievement, through the creation of the first modern bar associations in the eighteen-seventies. In its broad outlines this pattern of alternating light and shadow appeals strongly to the imagination, while providing at least a plausible account of the interplay between legal groups and the forces of social change. But the closer one scrutinizes the thesis, the less satisfactory do its major assumptions appear.

To begin with, the argument overemphasizes the role of formal organization as the appropriate yardstick by which to measure the strength of professionalism within the bar. This initial bias leads in turn to a neglect of alternative methods for maintaining discipline and esprit de corps among practitioners, just as it imposes upon early bar associations attitudes and norms that properly belong only to the twentieth century. Sporadic popular criticism of lawyers is likewise magnified at key points into something approaching a coherent class movement, which acts as a catalyst

"Department of History, Catholic University of America. 
to force undesirable changes upon a disapproving, but largely defenseless, bar. The "degradation" of the nineteenth-century lawyer thus becomes a function of external pressures and interference, rather than tensions within the legal profession itself. Any thoroughgoing revisionist theory must, of course, rely for its persuasiveness upon detailed research into professional behavior on both state and local levels; and few studies of this kind, employing the latest social science techniques, exist at the present time. Yet there is ample evidence to support a working hypothesis that the crucial "middle period" of the nineteenth century represented no sharp break with the past so far as legal professionalism was concerned. Arguably, practitioners in Jacksonian America and the Civil War era were more apt than their predecessors to cherish a narrow vocational outlook toward their work and to insist upon a technical competence that set them apart from their fellow men, as it enabled them to justify their elite status in American society on utilitarian grounds that made some sense even to radical democrats.

Consider first of all the conditioning effect of public opinion upon the bar. While it is possible to write the social history of the American lawyer in terms of recurrent crises in public relations, the truth seems to be that the American people have at all times distrusted attorneys. The roots of popular suspicion perhaps inhere in the very structure of common-law justice-a system that places a premium upon aggressive individualism, pitting the self-interest of the client against that of his legal representative in matters of cost and efficiency. Throughout the nineteenth century, at any rate, anti-lawyer protest is overwhelmingly a middle-class protest that centers upon demands for cheaper and speedier justice. Even the extremist rhetoric of agitators like Benjamin Austin in the early postrevolutionary years fits into a pattern of bourgeois norms and objectives. While Austin, who was himself a Boston merchant, called dramatically at times for the total annihilation of lawyers, the logic of his argument looked rather toward the retention of a small, efficient bench and bar, paid and controlled by the State. Other pamphleteers, of a less flamboyant stripe, agreed that a cadre of government lawyers would likely prove the answer to a thrifty bourgeois' dream. One anonymous Massachusetts critic even calculated the precise number of practitioners who would be required to staff the new establishment in his state. A work force of twenty-five elective attorneys, he maintained, could handle the legal business that was presently parceled out in haphazard fashion among some eighty competing lawyers. Through strictly enforced legislative fee tables litigants could secure the best law learning at one-third to one-fourth the existing cost; while practitioners 
would be assured of a "decent and genteel living" so long as they remembered to "use the persons well for whom they do business." 1

None of these early reorganization schemes ever went into effect; but they merit special attention because they typify the nature of the tug-of-war between the public and the legal profession that persisted throughout the nineteenth century. Although popular attacks upon the bar assumed many different guises, they remained essentially reformist efforts designed to impose greater social responsibility upon a fragmented and individualistic legal community. At issue, in other words, is not irresponsible lowerclass radicalism, but the concern of an ever-expanding bourgeoisie for increased legal services and an updated recruitment program geared to changing population trends and the rise of marginal social groups to positions of status and power. The drive toward reduced educational qualifications for lawyers parallels and complements the agitation by lower-middle-class constituencies for liberalized divorce laws and the efforts of small businessmen to secure general incorporation acts. In all three instances public opinion was sharply divided, both inside and outside the bar; and reform-minded lawyers, who were fully as conscientious as their opponents, played a leading role in promoting what they considered progressive legislative programs.

The general integrity of these nineteenth-century legal crusaders should be stressed, because historians have tended all too often to dismiss them out of hand as unprincipled demagogues, ready to sell out their profession for a handful of votes. This, of course, was precisely the view taken by the conservative legal elite of the time; and the approach of later commentators to the whole question of reform has been colored by an appreciable Whiggish bias. Scholars have accepted almost without question the jeremiads of Story, Kent, Hoffman, and Binney; students of the nineteenthcentury "legal mind" consider their outlook normative; and even revisionists are far more likely to try to establish that Marshall and Story were really "liberals" than to re-examine the goals and attitudes of their allegedly "radical" contemporaries. Clearly the time has come to take a fresh look at the entire process of adjustment by which the bar was brought into line with the aspirations of a fluid democratic society; and one essential starting-point must be a more

1. Worcester Magazine, vol. 2 (Nov. 1786), 382. See also: “Proposal for a more speedy and less expensive method of deciding causes judicially through the Commonwealth of Massachusetts, than what is now practised," Boston Magazine, vol. 1 (Apr. 1784), 226-228; "The Politician. No. II," Massachusetts Magazine, vol. I (Aug. 1789), 500; "On the Gratuitous Administration of Justice," American Monthly Magazine, vol. 1 (Sept. 1829), 369-378. 
open-minded inquiry into the reasonableness of popular complaints against the early bench and bar.

Although the legal community in the pre-Jackson period is generally pictured as a semi-autonomous guild struggling to maintain professional standards against the encroachments of antiintellectual legislative majorities, much evidence suggests that a professional outlook, in relation to corporate power and responsibilities, scarcely existed among lawyers of the time. Recent studies have pointed to a crucial "generation gap" within the bar that accompanied the Revolution, as one-fourth of all prewar practitioners joined the Tory Exodus. ${ }^{2}$ The disappearance of this conservative group, whose members were often bar leaders in their respective colonies, may well have permanently deflected any incipient drive toward corporatism; for their replacements tended to be younger, ill trained, and strongly individualistic in outlook. Even in Massachusetts, where several county bar associations flourished in the postrevolutionary years, all efforts to establish a state-wide organization failed; and the eventual recognition in 1810 of the power of county bar groups to control local admission standards was the work of sympathetic Massachusetts judges rather than lobbying lawyers.

Everywhere, in fact, it was the judiciary, not the bar, that did most to establish the guidelines for legal practice, with the acquiescence of state legislatures; and this pattern of joint legislativejudicial regulation persisted through the stormy middle decades of the century. Outside New England early bar associations were virtually non-existent, while an almost total absence of organizational data makes it impossible to determine whether most pioneer bar groups actually functioned as anything more than fraternal gatherings of practitioners attached to a particular set of local courts. Gerard W. Gawalt, the most careful student of the Massachusetts bar in this early period, has pointed out that the leading county bar associations had been transformed into quasi-social clubs at least as early as 1806 -several years before they won what he terms their "fifty-year struggle" for autonomy. Gawalt further concludes (and quite persuasively) that the subsequent dissolution of these organizations in the 1830's was due less to outside pressures than to a general apathy among the members themselves. ${ }^{3}$

2. See, for example: Charles R. McKirdy, "Lawyers in Crisis: The Massachusetts Legal Profession, 1760-1790," (unpublished Ph.D. dissertation, Dept. of History, Northwestern University, 1969), 147-149.

3. Gerard W. Gawalt, "Massachusetts Lawyers: A Historical Analysis of the Process of Professionalization, 1760-1840," (unpublished Ph.D. dissertation, Dept. of History, Clark University, 1969), 86-87, 110-125. 
Certainly far too much emphasis has been placed upon the closing of a few bar associations in the heyday of Jacksonian Democracy. In each instance one can point to the corresponding rise of new legal organizations at the same time-voluntary social groups, to be sure, but ones that, like the New York Law Association of the 1830's, often displayed a more intense professional consciousness than their earlier counterparts, along with a surer grasp of public relations techniques.

If commentators wish to assess fairly the general competence of the early bar, they must somehow move beyond problems of formal control and statutory criteria to the implementation of professional standards by courts and examining committees. While the present state of research precludes generalization of any kind, it may be noted in passing that the Philadelphia bar-probably the most prestigious in the nation at the close of the eighteenth century - was by no means a model of professional self-policing. Horace Binney, who passed his qualifying examinations in March, 1800, was frankly shocked at the laxity of admissions procedures. "No attention was paid at that time to the qualification of age, or, indeed, any other," Binney later recalled. "One of my examiners . . . did not know what was the general issue in an action of trover, and he knew about as much of law in general." " One could readily amass counterstatements from other individuals, of course; but if a systematic survey were feasible, the results would in all likelihood support the comparison drawn by a law writer in 1840 between turn-of-the-century practitioners and those of his own day. "The labor of a lawyer was easy at that (early) period, compared with that of the present day," he observed; "there were few books of authority to be examined and cited; there were no volumes of reports scattered as now, like the leaves of the sibyl, upon his path, and the standard of legal acquirement was moderate. A good voice, a fluid utterance, and a discussion of general principles answered every demand ... ." 5

From this perspective the stringent state regulation of the bar that characterized the years after 1830 loses much of its shock impact. The scaling down of formal educational requirements, for example, which critics have so readily attributed to the antiintellectualism of a raw democracy, may equally imply a reasoned assault upon the privileged position of upper-middle-class practitioners and their sons; while the popular election or short-term appointment of judges presupposes no necessary decline in the

4. Charles Chauncey Binney, The Life of Horace Binney (1903), 37.

5. "Notes on the Early Jurisprudence of Maine," 3 Monthly L. Rep. $126(1840)$. 
caliber of the bench. A provocative recent study of state supreme courts in the Old South by A. E. Keir Nash in fact demonstrates that, where black litigants were concerned, most judges went out of their way to be scrupulously fair, often reading liberal commonlaw guarantees into the harsh provisions of state statutes. Nash further suggests that judges often got away with unpopular "liberal" decisions because the public recognized that the judicial role was inherently "non-gladiatorial," and hence applied a somewhat different set of standards in selecting judges than in choosing congressmen. ${ }^{6}$

But, whatever the practical effect of enlarged public regulation, conservative bar leaders did not remain passive in the face of what they at least considered a serious threat to the dignity and integrity of the legal profession. Instead, they set in motion an impressive public relations campaign that succeeded by the time of the Civil War in altering appreciably the popular image of the American lawyer-transforming him from a designing cryptopolitician into a benevolently neutral technocrat.

Law journals played a major role in this process of imageformation. They increased dramatically in number after 1830, but, more important, they narrowed both their format and their potential target audience. Where earlier publications (of which Hall's American Law Journal (1808-1817) was both pioneer and prototype) tended to be speculative and treated many subjects of general interest to the educated community, the typical magazine of the post-1830 years-such as the Monthly Law Reporter (1838-1866), New York Legal Observer (1842-1854), Pennsylvania Law Journal (1842-1848), and Western Law Journal (1843-1853)-disavowed all theorizing in an effort to serve the more limited interests of those whom one editor labeled "the workingmen of the profession." The bulk of every issue was devoted to the bare reporting of recent court decisions, in advance of their appearance in official volumes of reports, with heavy emphasis upon law-as-it-is rather than lawas-it-ought-to-be. And through obituary columns, book reviews, professional reminiscences, and essays on the improvement of office habits or courtroom tactics, readers were trained to regard themselves as a technical elite whose best opportunities for personal fulfillment and useful public service lay strictly within the confines of legal practice. Success at the bar was open to anyone of moderate intelligence and painstaking industry, writers urged; but one essential prerequisite was a full-time professional commitment to the law that precluded any flirtation with party politics,

6. Nash, "Fairness and Formalism in the Trials of Blacks in the State Supreme Courts of the Old South," 56 Va.L. Rev. 64 (1970). 
which had developed by the 1830's into a rival (though decidedly inferior) profession in its own right. Timothy Walker stated the case for the lawyers in exemplary fashion when he told a public audience in 1837: "I would hold up the legal profession as an end in itself, not as a stepping stone to something higher. In fact there is nothing higher. He who stands at the head of this profession is on a level with the most elevated in the land; and instead of owing his eminence to the solicited suffrages of others, he has the proud satisfaction of having achieved it for himself." ?

This stance of political detachment and technical expertise strongly affected the self-image of the American bar through the rest of the nineteenth century. As an influence on the behavior of lawyers it transcended political, geographical, and generational lines. One can trace its ramifications through the careers of such diverse figures as William Cabell Rives of Virginia, Peleg W. Chandler of Massachusetts, Hugh S. Legaré of South Carolina, Timothy Walker of Ohio, William Pitt Ballinger of Texas, and Roujet D. Marshall of Wisconsin. The theme of a depoliticized profession dominates the early correspondence of Manning F. Force, a young Harvard Law School graduate struggling to establish a practice in the Midwest in the 1850's, as it underlies the admonitions of Albert Gallatin Riddle to one of the early graduating classes of Howard Law School in the period following the Civil War. Moreover, the general public absorbed the idealism of the new-style professionals through one of two major channels: the lecture platform and the world of escapist entertainment.

A whole subgenre of mid-nineteenth century legal literature testifies to the importance that lawyers attached to lyceums, mechanics' institutes, and other agencies of popular education. As a substitute for partisan politics, speeches on broad and generally anodyne topics offered a unique opportunity to dispel popular myths about the bar while affirming the social utility of the lawyer's day-to-day services to the community at large. Stressing the interdependence of the professions and all social classes, lawyer-lecturers painted a glowing picture of themselves as basically skilled workers who were as totally dedicated to the discipline of their craft as any other workingmen. ${ }^{8}$ This view was

7. Timothy Walker, Introductory Lecture on the Dignity of the Law as a Profession (1837), 21-22. See also, in general: Bloomfield, "Law vs. Politics: The Self-Image of the American Bar (1830-1860)," $12 \mathrm{Am}$. J. Leg. Hist. 306 (1968).

8. See, for example: Timothy Walker, "Introductory Lecture Delivered before the Cincinnati Lyceum" (1831) and "Notes of a Lecture for the Mechanics' Institute, on the practicability and importance of a more general diffusion of legal knowledge among our young men" (1836), in 
translated into popular literature through the efforts of such lawyer-novelists as Frederick W. Thomas and William Price in the 1830 's. ${ }^{9}$ It found expression in one of the great comedy hits of the antebellum stage, The People's Lawyer, by Joseph S. Jones, which remained a standard repertory favorite for more than thirty years after its initial performance in 1839. And the profile of the apolitical private practitioner achieved its classic formulation in the pages of Mrs. E.D.E.N. Southworth's gargantuan Civil War novel, Ishmael, which still stands as the apotheosis of the lawyer in American fiction.

Based allegedly upon the career of William Wirt, Ishmael first appeared as a serial in Robert Bonner's famous story paper, the New York Ledger; but its immediate popularity led author Emma Southworth to reissue it in an expanded hard-cover edition of two volumes: Ishmael; or, In the Depths and Self-Raised; or, From the Depths (1864). Each volume sold more than two million copies, making the story one of the top ten best sellers of the entire nineteenth century. The plot chronicles the rise to legal fame of high-minded Ishmael Worth-a rare combination of George Washington, Horatio Alger, and Little Orphan Annie-who represented (at least in Mrs. Southworth's eyes) the perfect male. Ishmael's egregious piety turns off a modern reader in short order; but to audiences in the Gilded Age he figured as a genuine folk hero, in whom the myth of the self-made man was successfully fused with the legal profession's own preferred vision of its role in American society.

That role, incidentally, while abjuring all involvement in partisan politics or the electoral process, did not rule out other approaches to government service. In keeping with the philosophy of a managerial elite, legal publicists of the mid-nineteenth century argued for the creation of expert administrative commissions, staffed by skilled apolitical lawyers, to review the work of state legislatures, to frame uniform national laws, and to engage in other projects of broad social planning. The Civil War brought at least a partial fulfillment of these designs with the establishment

Walker Papers, Cincinnati Historical Society; Emory Washburn, A Lecture Read before the Worcester Lyceum, March 30th, 1831 (1831); Job R. Tyson, Discourse on the Integrity of the Legal Character (1839); William A. Duer, The Duties and Responsibilities of the Rising Generation (1848); and Daniel Lord, On the Extra-Professional Influence of the Pulpit and the Bar (1851).

9. Frederick W. Thomas, Clinton Bradshaw; or, The Adventures of a Lawyer (1835); William Price, Clement Falconer; or, The Memoirs of a Young Whig (1838). 
of such agencies as the United States Sanitary Commission; and in the postwar years legal ideologues gravitated toward Mugwump politics, Civil Service reform, and the movement for independent regulatory commissions (although in the latter case lawyers found themselves competing for appointment with businessmen whose economic expertise often outweighed their own).

In matters of bar organization and morale the Gilded Age period likewise witnessed a continuation of prewar trends. The state bar associations that mushroomed after 1870 tended to be voluntary (and often highly selective) social clubs, as did the first national organization-the American Bar Association of 1878 - fourteen of whose first thirty presidents held no significant political post of any kind during their entire lives. The difficulty of maintaining a legal practice while engaged in professional politics continued to increase, as David J. Rothman has shown in his able study of the United States Senate from 1869 to 1901; and, while the post-Appomattox public no longer feared its lawyers as a distinct aristocratic caste, the relative absence of later public regulation permitted the bar to pursue once more a policy of narrow self-interest that drastically obstructed the recruitment and assimilation of such aspiring social groups as Negroes, women, and East European immigrants. For all its occasional excesses, the oft-criticized antebellum legislation at least did not $\sin$ in this direction; but by forcing attorneys to open their ranks to a broader segment of the community, it aimed at making the bar what many lawyers in every age have thought it should be: a career genuinely open to talent. 